\title{
Comparison of Zea diploperennis and Zea mays under water stress conditions
}

\author{
Alberto-Daniel GOLBERG, Jean-François LEDENT \& Charles RENARD \\ Université Catholique de Louvain. ECOP (Grandes Cultures), 2, place Croix-du-Sud, B 1348 Louvain-la-Neuve, \\ Belgique
}

Additional key words : Water potential, leaf conductance, photosynthesis.

Les effets d'un arrêt de l'arrosage furent étudiés chez Zea diploperennis (Z.D.) et chez le maïs en conditions contrôlées. Le contenu en eau du sol des conteneurs oủ croissait Z.D. baissa plus rapidement, indiquant une transpiration plus élevée chez Z.D. (par rapport au maïs). Malgré cela, la conductance foliaire (G) de Z.D. fut maintenue à sa valeur initiale pendant les deux premières semaines qui suivirent, alors que chez le maïs une chute de $\mathrm{G}$ fut observée rapidement. De plus, lors de la reprise des arrosages, les valeurs de $\mathrm{G}$ du maïs ne se rétablirent pas rapidement au niveau des témoins comme ce fut le cas chez Z.D. Finalement, la masse sèche et la surface foliaire du maïs furent plus affectées par la sécheresse. A potentiel hydrique foliaire équivalent, la photosynthèse et $G$ de Z.D. furent moins réduites par le stress hydrique que chez le maïs.

Mots clés additionnels : Potentiel hydrique, conductance foliaire, photosynthèse.

\section{INTRODUCTION}

Zea diploperennis Iltis, Doebley, Guzman is a primitive relative of Zea mays L. discovered recently (ILTIS et al., 1979). The species crosses easily with maize and might therefore be used to bring new germplasm into a maize breeding programme (GALINAT, 1980; GAY, 1984). For this reason, an investigation was started on physiological characters of Zea diploperennis (which will be referred to as Z.D.) in comparison with maize.

Since we intend to study in future the behaviour of interspecific hybrids between maize inbred lines and Z.D. we chose as a first step to compare Z.D. with one maize inbred line. In this paper we examine, under controlled conditions, the effect of water stress on photosynthetic capacity $\left(\mathrm{CO}_{2}\right.$ exchange rate, $\left.\mathrm{CER}\right)$, stomatal opening (leaf conductance, $\mathrm{G}$ ), and dry matter. Photosynthetic rates per unit leaf area may differ among genotypes, and this character might have some value in maize breeding (CROSBIE et al., 1981 ; MOROT-GAUDRY et al., 1981).

On the other hand, water can be a very important factor limiting productivity (MORIZET et al., 1984; Algans \& DESVIGNES, 1984) and CER of maize can be drastically affected by water stress (MCPHERSON \& BOYER, 1977).

\section{MATERIALS AND METHODS}

\section{A. Plant material, conditions of growth}

Seeds of Z.D. (Zea diploperennis) were harvested in 1983 on plants grown in the botanical garden of INIREB (Xalapa, Mexico). Maize seeds were commercial seeds on inbred line $F_{1}$ from I.N.R.A., France. 
TABLE 1

Water stress treatmonts and physiological measurements.

Traitements (contrainte hydrique) et mesures de paramètres physiologiques.

\begin{tabular}{|c|c|c|c|c|c|c|c|}
\hline & $\begin{array}{l}\text { Beginning of } \\
\text { cessation of } \\
\text { watering (days } \\
\text { after sowing) }\end{array}$ & $\begin{array}{l}\text { Number of } \\
\text { expanded leaves } \\
\text { at onset of } \\
\text { treatment }\end{array}$ & $\begin{array}{l}\text { Duration of } \\
\text { treatment (days) }\end{array}$ & $\begin{array}{l}\text { Harvest (days } \\
\text { after sowing) }\end{array}$ & Measurements ${ }^{1}$ & $\begin{array}{l}\text { Leaves measu- } \\
\text { red (position on } \\
\text { the shoot } \\
1=\text { uppermost } \\
\text { expanded leaf) }\end{array}$ & $\begin{array}{l}\text { Number of } \\
\text { leaves measured } \\
\text { for each date } \\
\text { and treatments }\end{array}$ \\
\hline & $\begin{array}{l}\text { Début de l'arrêt } \\
\text { de l'arrosage }\end{array}$ & $\begin{array}{l}\text { Nombre de feuil- } \\
\text { les déployées au } \\
\text { début du traite- } \\
\text { ment }\end{array}$ & $\begin{array}{l}\text { Durée du traite- } \\
\text { ment (jours) }\end{array}$ & $\begin{array}{l}\text { Récolte finale } \\
\text { (jours après le } \\
\text { semis) }\end{array}$ & Mesures & $\begin{array}{l}\text { Feuilles mesu- } \\
\text { rées ( } 1= \\
\text { dernière feuille } \\
\text { déployée) }\end{array}$ & $\begin{array}{l}\text { Nombre de feuil- } \\
\text { les mesurées }\end{array}$ \\
\hline Containers & 25 & 6 & 13 & 40 & $\theta_{\mathrm{w}}, \mathrm{G}^{1}, \psi_{1}, \psi_{\mathrm{s}}$ & 1 or 2 & 5 \\
\hline Pots & 54 & $8-9$ & 8 & $\begin{array}{c}\text { Plant discarded } \\
\text { after measure- } \\
\text { ment }\end{array}$ & $G, \mathrm{CER}, \psi_{1}$ & 2 or 3 & 6 \\
\hline
\end{tabular}

$1=\theta_{\mathrm{w}}:$ soil water content (percentage on dry weight basis) : Teneur en eau du sol (sur la base du poids sec).

$\mathrm{G}$ : leaf diffusive conductance; Conductance stomatique.

$\psi_{1}$ : leaf water potential ; Potentiel hydrique foliaire.

$\psi_{s}$ : leaf osmotic potential ; Potentiel osmotique foliaire.

CER : $\mathrm{CO}_{2}$ exchange rate; Taux d'échange du $\mathrm{CO}_{2}$ (photosynthèse).

After germination in Petri dishes at $24^{\circ} \mathrm{C}$, seeds were transplanted in containers. An additional series of seeds was transplanted to pots. Pots and containers were placed in growth chambers (PGV 36, from Controlled Environment).

Containers were $80 \times 50 \mathrm{~cm}$ by $64 \mathrm{~cm}$ depth. There were four containers (two for each species). Each contained a bottom layer of gravel $(10 \mathrm{~cm}$ thick) and a top layer $(40 \mathrm{~cm})$ of a fifty-fifty sand/loam mixture. There was no opening in the containers for drainage. Water was supplied through perforated pipes buried $35 \mathrm{~cm}$ below the soil surface. The quantities provided were not recorded. In each container plants were placed in 2 rows $34 \mathrm{~cm}$ apart.

In the growth chamber plants were kept under a $10 \mathrm{~h}$ photoperiod and $21^{\circ}$ (day), $15^{\circ}$ (night) temperatures. Air relative humidity was $60 \%$ (day) and $80 \%$ (night). Photosynthetic photon flux density on plant tops was $250 \mu \mathrm{mol} \mathrm{m}^{-2} \mathrm{~s}$.

The pots used for the additional series of plants (16 pots per species) had a $24 \mathrm{~cm}$ diameter and contained a mixture of $25 \%$ sand, $25 \%$ peat, $50 \%$ loam. In each pot the number of shoots was limited to three: three plants in the case of maize, or one plant trimmed to its main shoot and two tillers in the case of Z.D. Other tillers were removed as soon as they became visible.

\section{B. Water stress treatments}

Watering was withheld on half the containers and pots as indicated in table 1 . The other half was used as control. We tried to maintain soil water content of controls at $80-90 \%$ field capacity (f.c.). Field capacity was considered to correspond to $\mathrm{pF}=2.5$, and permanent wilting point to $\mathrm{pF}=4.2$. From curves of $\mathrm{pF}$ as a function of $\theta_{w}$ field capacity in containers appeared to correspond to $\theta_{\mathrm{w}}=8.7 \%$ and permanent wilting point to $\theta_{\mathrm{w}}=5.7 \%$.

\section{Environmental and physiological measurements}

The water content of the soil in the containers was determined gravimetrically on 3 samples. No measurements of water content were made on the soil in pots. Leaf diffusive conductance $(G)$ was measured using a diffusive porometer (Delta T, Cambridge). Total conductance was obtained summing $G$ on adaxial and abaxial surface. In the case of Z.D. measurements were soon limited to the abaxial surface since $G$ on adaxial surface was found to be negligible, as in a previous study (GolberG \& Renard, unpublished data). Leaf water potential $\left(\psi_{1}\right)$ was determined on leaf parts $5 \mathrm{~cm}$ long using a membrane press (J-14 Press, Crump, Raleigh). With a hydraulic pump, a pressure is applied on a flexible membrane, pushing the leaf material against the translucid wall of a chamber. The pressure applied when sap flows out of the leaf and change in the leaf coloration occurs is recorded. A close relationship exists between the results obtained with this method and the measurements made with a pressure bomb (RENARD \& NDAYISHIMIE, 1982).

$\mathrm{CO}_{2}$ exchange rates (CER) were measured using a slightly modified version of a rapid $\mathrm{CO}_{2}$ pulse method described by SHIMSHI (1969).

Light was provided by 4 mercury vapour lamps of $400 \mathrm{~W}$ each. A transparent tank through which water was flowing was placed as a screen between lights and plants. Air containing $385 \mu \mathrm{Il}^{-1} \mathrm{CO}_{2}+{ }^{14} \mathrm{CO}_{2}$ with a specific activity of $61406 \mathrm{dpm} / \mathrm{ml}$ was passed through a miniature assimilation chamber $(8 \mathrm{~mm}$ diameter). Clamping the chamber on the leaf for $20 \mathrm{~s}$ released an air flow (speed $3.9 \mathrm{~cm} \mathrm{~s}^{-1}$ ) on both sides of the enclosed leaf part. Air temperature was $20^{\circ} \mathrm{C}$, and RH $50 \%$.

Immediately afterwards the treated leaf part was punched out and subjected to chemical digestion with Soluene before being processed for counting in a Packard Tricarb liquid scintillation counter. We are aware of conflicting results in the literature concerning comparison of CER measured by this method and with the infra red gas analyzer (IRGA) : see for instance $V_{A N}$ DijCK \& LEDENT, 1984 ; KeMP \& BlackLOW, 1984. The 
method is simple and convenient (portable equipment, rapidity) and it seems sufficient when no absolute values of CER are needed.

With a few exceptions, physiological measurements were taken at least daily after cessation of watering. Measurements of the different parameters (table 1) were made successively on the same leaves. $G$ were measured at different hours per day but since the same trend through days was observed only daily averages will be discussed. For measurements of photosynthesis plants in pots were removed from the growth chamber at $9 \mathrm{a} . \mathrm{m}$. and brought to the laboratory. They were placed 30 minutes under a PPFD (photosynthetic photon flux density) of $500 \mu \mathrm{mol} \mathrm{m}{ }^{2} \mathrm{~s}^{1}$ then PPFD was increased to $1200 \mu \mathrm{mol} \mathrm{m}^{-2} \mathrm{~s}^{1}$ and measurements started $30 \mathrm{mi}$ nutes later. After measurement of photosynthesis, plants in pots were discarded.

Leaf area of all leaf laminae was measured at the end of the experiment with an electronic leaf area meter (AAM-7, from Hayashi Denko). Dry weights of different plant parts (laminae, stems,...) were determined after drying at $80^{\circ} \mathrm{C}$ for $48 \mathrm{~h}$.

\section{RESULTS}

\section{A. Soil water content}

Soil water content, $\theta_{\mathrm{w}}$ (percentage on dry weight basis) of controls in containers showed erratic variations between $75 \%$ and $120 \%$ f.c. When water was witheld $\theta_{\mathrm{w}}$ decreased very regularly in a linear fashion, to reach $50-60 \%$ of f.c. just before watering was resumed. The decrease was faster in the case of Z.D. (fig. 1). A $\theta_{w}$ value of $5.6 \%$ was reached $8 \mathrm{DCW}$ (Days after Cessation of Watering) in the case of Z.D. whereas in maize it took 12-13 DCW to reach that value. Thus transpiration by Z.D. was higher than for maize. This result may be explained by the higher leaf area of Z.D.

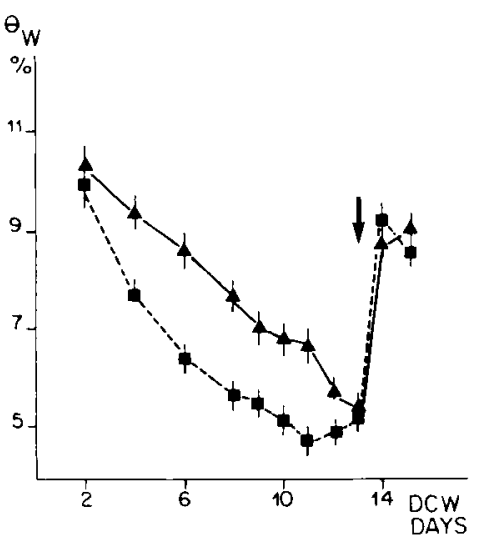

Figure 1

Soil water content, $\theta_{w}, \%$ on a dry weight basis) in containers with Zea diploperennis $(Z . D.) \mathbf{\square}$, or maize $\boldsymbol{\Delta}$, with time (in days after cessation of watering $D W$.

Vertical lines correspond to $s_{\gamma}$ of each mean presented. The arrow indicate restamption of watering.

Teneur en eau du sol, $\theta_{w}$ (p. 100 sur la base du poids sec) dans les récipients contenant Zea diploperennis (Z.D.) $\mathbf{\square}$, ou le maïs $\boldsymbol{\Delta}$, en fonction du temps (en jours, après l'arrêt des arrosages, $D C W$ ).

Les lignes verticales correspondent à $x_{\chi}$ (écart-type de la molvenne). La fliche indique la reprise des arrosages. (see below) and/or a higher transpiration rate per unit leaf area. No measurements of soil water content were made on plants growing in pots.

\section{B. Leaf water potential}

In containers $\psi_{1}$ of controls remained around - 0.2 $\mathrm{MPa}$ at all times. Cessation of watering had no effect on $\psi_{1}, \psi_{\mathrm{s}}$ or $\psi_{\mathrm{p}}$ (pressure potential) (data not presented) during an initial period (IP) of $6 \mathrm{DCW}$. The following days a drop of $\psi_{1}$ was observed and values of

1.2 and - 1.4 MPa (Z.D. and maize respectively) were finally reached. Plots of $\psi_{1}$ versus $\theta_{w}$ are presented in figure 2. The association of $\psi_{1}$ with $\theta_{w}$ was looser in the case of Z.D. ( $r=0.89^{* *}$ for maize and $r=0.65$ N.S., $\mathrm{p} \leqq 0.05$ for Z.D. ; corresponding slopes were 0.15 N.S. and $\left.0.25^{* *}\right)$. Fitting the equations $\ln \left(\psi_{1}\right)=\mathrm{a}+\mathrm{b} \theta_{\mathrm{w}}$ gave values of $b=-0.54$ and $-0.26, a=3.30$ and 0.93 , $\mathrm{r}=-0.95^{* *}$ and 0.61 N.S., for maize and Z.D. respectively. In plants grown in pots stressed maize showed significantly lower $\psi_{1}$ than Z.D. starting 3 days after cessation of watering.

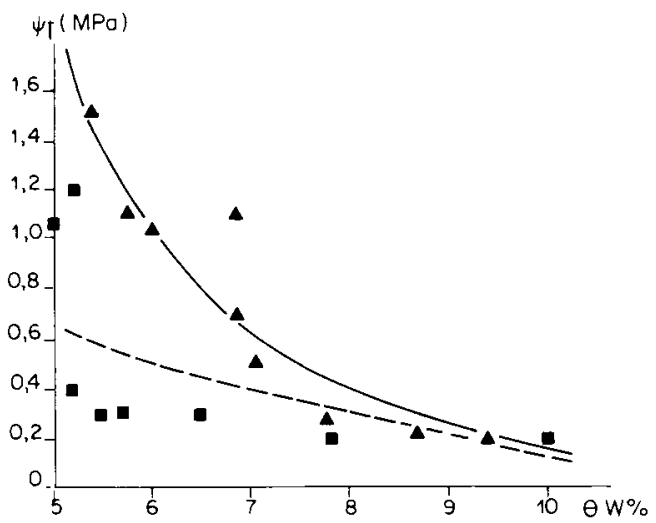

Figure 2

Leaf water potential $\psi_{2}(M P a)$ in relation to soil water content $\theta_{1}$ (1) ; experiment in containers. Values of $\psi_{i}$ calculated from the model In $\left(\psi_{l}\right)=a+b \theta_{w}$ are also presented.

Potentiel hydrique foliaire $\psi$ (Mega Pascals, MPa) en fonction du contemu en eau du sol $\theta_{w}$ (p. 100); expérience en conteneurs. Les valeurs de $\psi_{1}$ prédites à partir de $l n\left(\psi_{1}\right)=a+b \theta_{1}$ sont également indiquées.

$\mathbf{0}$ : Zea diploperennis -... $\quad \mathbf{\Delta}$ : Zea mays

\section{Leaf diffusive conductance}

In containers, leaf diffusive conductance ( $G$, fig. 3 ) of plants deprived of water remained relatively constant during the initial period (IP) of $6 \mathrm{DCW}$ for both species. Differences between maize and Z.D. appeared afterwards : after a small decrease at day $6(\mathrm{DCW}) \mathrm{G}$ of Z.D. remained remarkably constant (around $0.12 \mathrm{~cm} \mathrm{~s}^{1}$ ) whereas in maize a continuous decrease to $0.05 \mathrm{~cm} \mathrm{~s}^{1}$ was recorded. Only on day 13 , a decrease of $G$ (to values of $0.05 \mathrm{~cm} \mathrm{~s}^{-1}$ ) was observed for Z.D., i.e. one week later than for maize. Thus, despite lower soil water contents, Z.D. maintained higher $G$ than maize.

Only a sample of control values for $G$ are presented in figure 3 to improve readability. $G$ values started from similar values and showed the same trend with time in 
both species. An increase of $\mathrm{G}$ with time, associated with the reproductive stage, has been reported in other species such as millet (HANSON et al., 1983). In maize plants growing in pots complete stomatal closure $(G \simeq 0)$ was observed at the 4th DCW. In Z.D. on the contrary G remained little affected until the 6th day, when a drop was recorded, but even at that stage stomata were not completely closed $(G \neq 0)$. Plots of $G$ versus $\psi_{1}$ for the period starting after cessation of watering are presented in figure 4 (plants in containers). Linear regression fitted to the data in figure 4 gave a higher slope in the case of maize $\quad\left(b=0.17^{* *} \mathrm{~cm} \mathrm{~s}{ }^{3} \mathrm{MPa}\right.$ for maize and $b=0.09^{* *}$ for Z.D.). Moreover the relationship was looser in the case of Z.D. : corresponding coefficients of correlation were indeed $\mathrm{r}=0.89^{* *}$ and $0.59^{* *}$ (for maize and Z.D. respectively). Comparable results were obtained with plants growing in pots $: b=0.18^{* *}$ and 0.12 N.S. ; $r=0.90^{* *}$ and 0.57 N.S. (maize and Z.D. respectively). Thus a decrease in $\psi_{1}$ had less effect on $\mathrm{G}$ in Z.D. than in maize.

\section{Recovery}

When watering was resumed, recovery was very fast for $\psi_{1}$ and its components : for both species return to control values took less than 2 days. Recovery was also fast for $G$ values in Z.D. but not in maize (fig. 3),

\section{E. $\mathrm{CO}_{2}$ exchange rate}

CER of maize decreased rapidly after cessation of watering (plants in pots). It reached nil values the 4th day after the onset of treatment. In Z.D. the decrease was more gradual and the last day of measurement CER still reached $50 \%$ of the rate observed in the controls.

In maize where stomatal conductance $(\mathrm{G})$ was drastically affected by cessation of watering a relatively close association existed between CER and $\mathrm{G}\left(\mathrm{r}=0.81^{* *}\right.$, d.f. 13).

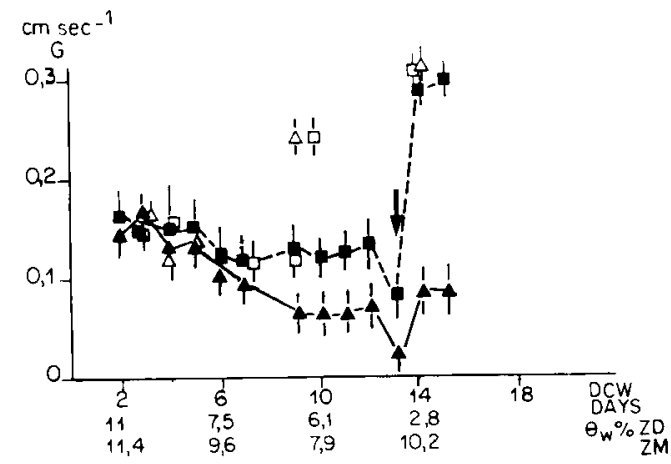

Figure 3

Leaf diffusive conductance $G\left(\mathrm{~cm} \mathrm{~s}^{1}\right)$ with time $(D C W)$; experiment in containers. Corresponding values of $\theta_{11}$ for Z.D. (Zea diploperennis) and Z.M. (Zea mays) are also given in abscissa.

Conductance stomatique $G(\mathrm{~cm} \mathrm{~s}$ ') en fonction du temps (DCW): experience en containers. Les valeurs correspondantes de la teneur en eau du sol $\theta_{\mathrm{w}}$ sont également indiquées en abscisse.

Z.D. (Zea diploperennis)
Control Stressed
Témoin Stressé
l

Maize, maïs (Z.M.) Control Stressed Témoin Stressé

Vertical lines correspond to $s_{\chi}$. Les lignes verticales correspondent à $s_{\chi}$

In Z.D. where stomatal opening was less alfected the corresponding correlation was not significant $(\mathrm{r}=0.26$ N.S. ; d.f. 28). Correlations between CER and $\psi_{1}$ gave similar results $\left(r=0.82^{* *}\right.$, and 0.26 N.S. for maize and Z.D. respectively).

Plots of CER as a function of $\mathrm{G}$ or $\psi_{1}$ showed a great dispersion of CER values at some $G$ or $\psi_{1}$ values. Heterogeneity within the leaf (small assimilation chamber : $8 \mathrm{~mm}$ diameter) and sampling of leaves differing in positions and therefore age and microclimate might explain partly this result. To homogenize the results CER values obtained for second uppermost leaves were discarded if they differed more than $30 \%$ from the value obtained for uppermost leaves, moreover we

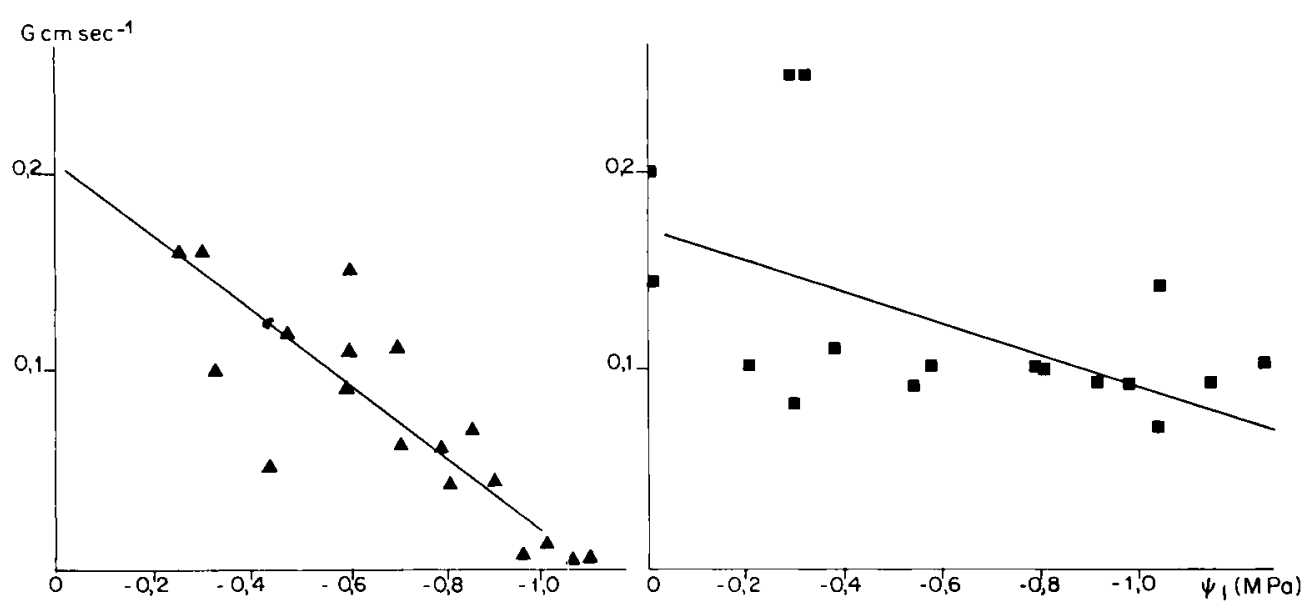

Figure 4

Leaf diffusive conductance $G\left(\mathrm{~cm} \mathrm{~s}^{-1}\right)$ in relation to leaf water potential $\left(\psi_{t}\right)$, plants in containers. Regression equations are $G=0.17 \psi_{t}+0.20$ for Zea diploperennis and $G=0.9 \psi_{l}+0.17$ for maize.

Conductance stomatique $G\left(\mathrm{~cm} \mathrm{~s}^{1}\right)$ en fonction du potentiel hydrique foliaire $\left(\psi_{t}\right)$, plantes en conteneurs. Les équations de régression sont $G=0,17 \psi_{l}$ $+0,20$ pour Zea diploperennis et $G=0,09 \psi_{1}+0.17$ pour le mails.

+ : Zea diploperennis - - - - 
discarded data from pots where a difference of more than $30 \%$ was observed between the shoots (tillers or plants within the same pot). The screened data are presented in figure 5 (relationship of CER vs $\psi_{1}$ ) and figure 6 (relationship of CER with $G$ ). Correlations calculated on screened data were $0.93^{* *}$ (maize) or 0.31 N.S. (Z.D.) for the relation CER, G, and $0.78^{* *}$ (maize) or $0.49^{*}$ (Z.D.) for the relation CER, $\psi_{1}$. They lead to the same conclusions as those reached from the correlations on rough data.

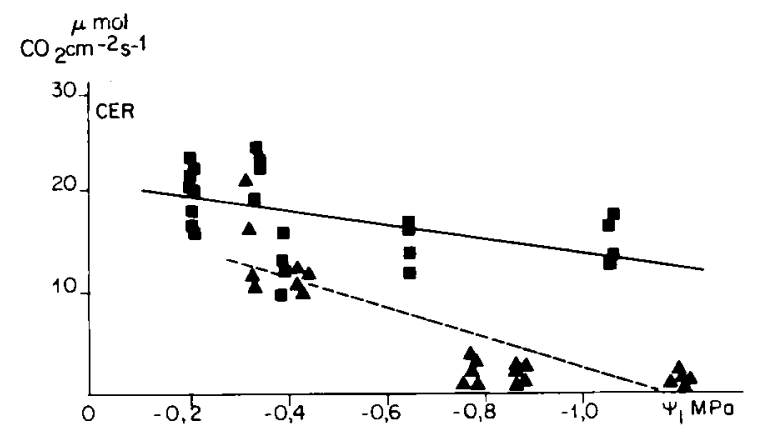

Figure 5

Relationship between CER and $\psi_{1}$ (screened data). CER was measured at $20{ }^{\circ} \mathrm{C}$, under a $1200 \mu \mathrm{mol} \mathrm{m}^{2}{ }_{s}^{\prime}{ }^{\prime}$ photosynthetic photon fux density. Relation entre CER et $\psi_{1}$ (données criblées). CER a été mesuré à $20^{\circ} \mathrm{C}$ sous une densité de flux de photons de 1200 umoles $\mathrm{m}^{-2}{ }^{2}$.

口 : Zea diploperennis $\quad \mathbf{a}$ : Zea mays

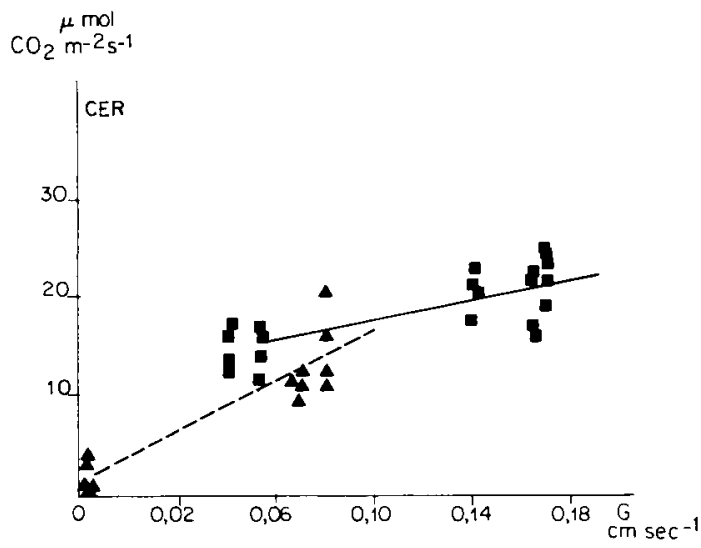

Figure 6

Relationship between CER and $G$ (screened data).

See explanation and symbols in figure 5.

Relation entre CER et $G$ (donnćes criblées).

Voir les explications et les symboles à la figure 5 .

Figure 5 indicates that CER of maize was completely inhibited when $\psi_{1}$ was about $-1 \mathrm{MPa}(-10 \mathrm{bar})$.

Similar (BEADLE et al., 1973) but also lower values (- 2 MPa, MCPHERSON \& BOYER, 1977) are found in the literature hence these numbers should not be taken as applying generally.

CER of Z.D. was less affected since at $\psi_{1}$ values of $-1 \mathrm{MPa}$ it still reached about $50 \%$ of the control value. The same result is obtained with $G$.

\section{F. Leaf area and dry matter}

Drought reduced total shoot dry weight by $42 \%$ in maize and by $22 \%$ in Z.D. (plants growing in contai- ner, table 2). The interaction treatment $\times$ species was highly significant. Therefore dry matter was more reduced by drought in maize than in Z.D., a result found also for stomatal conductance. Leaf area was also more reduced in maize ( $29 \%$ in maize, versus $23 \%$ in Z.D.). The higher leaf area values for Z.D. were associated with its tillering capacity (3-6 tillers per plant in containers and pots respectively) and occurred despite a smaller leaf area per shoot (a mean surface area per leaf lamina of $2.1 \mathrm{dm}^{2}$ (maize) and $0.6 \mathrm{dm}^{2}$ (Z.D.) was observed on plants in pots. Number of tillers in Z.D. was reduced $14-20 \%$ by drought.

TABLE 2

Effect of water stress on leaf area and total dry weight (experiment in containers).

Effet d'une contraimle hydrique sur la surface foliaire et le poids sec total (experience en conteneur).

\begin{tabular}{|c|c|c|c|c|c|}
\hline & \multicolumn{2}{|c|}{ Zea mays } & \multicolumn{2}{|c|}{ Zea diploperennis } & \multirow{2}{*}{$\begin{array}{l}\text { LSD (ppds) } \\
\mathrm{p} \leqq 0.05\end{array}$} \\
\hline & Control & Stressed & Control & Stressed & \\
\hline $\begin{array}{l}\text { Leaf } \\
\text { area/plant } \\
\left(\mathrm{dm}^{2}\right) \\
\text { Surface foliai- } \\
\text { re/plante } \\
\left(\mathrm{dm}^{2}\right)\end{array}$ & 17.1 & 12.2 & 22.5 & 17.3 & 6.87 \\
\hline $\begin{array}{l}\text { Total shoot } \\
\text { dry weight }(\mathrm{g}) \\
\text { Poids sec des } \\
\text { parties aérien- } \\
\text { nes }(\mathrm{g})\end{array}$ & 21.5 & 12.5 & 20.8 & 16.6 & 2.10 \\
\hline $\begin{array}{l}\text { Nb } \\
\text { tillers/plant } \\
\text { Nombre de } \\
\text { talles par } \\
\text { plante }\end{array}$ & 0 & 0 & 3.6 & 3.1 & 0.42 \\
\hline
\end{tabular}

Dead plant material was carefully harvested separately. The very low amounts obtained indicate that the drought treatments had little effect on tissue death in these experiments.

\section{CONCLUSIONS}

Higher leaf diffusive conductances $(G)$ were maintained in Z.D. than in maize, when watering was withheld. This result was observed although, during the drought period, soil in containers with Z.D. reached lower soil water content $\left(\theta_{\mathrm{w}}\right)$ than in containers with maize. In fact the lower soil water content obtained with Z.D. appears to be the result of a higher transpiration of Z.D., in relation with higher $G$ and larger leaf area. Higher $G$ in Z.D., despite higher loss of water, indicates a better maintenance of turgor in this species. Whether this may be attributed to differences in elasticity of cell walls or to other mechanisms such as osmotic adjustments etc... remains an open question.

The maintenance of a higher transpiration rate when water becomes limited is not, per se, an advantage. 
Maintenance of photosynthetic rates is. Higher CER were observed in Z.D. during the stress period.

The final dry weights obtained were consistent with the lesser reduction of $\mathrm{CO}_{2}$ exchange rate (CER) in Z.D. plants subjected to water shortage. Maintenance of higher $G$ was favourable to CER and dry matter production.

The disadvantage of maize, as far as CER is concerned, seems to be associated with greater effect of water shortage on $\mathrm{G}$, affecting growth through a close association of CER with $G$.

Such a close association is not observed in Z.D., but this is probably because of its higher $G$ values, corresponding to the part of the response curve of CER to $G$ which tends to plateau.

Reduction of photosynthesis at low water potentials is known to be due to stomatal closure, but also to other factors related to chloroplast activity and structure
(Vieira da Silva, 1976 ; Farquhar \& Sharkey, 1982 ; KRIEG \& HUTMACHER, 1986).

Measurements of fluorescence induction seemed to indicate, however, that the primary photochemistry of photosystem II was not affected and was not a cause for the reduction of CER in these experiments (GoLBERG et al., 1986).

Under our conditions and with the material we used Z.D. (Zea diploperennis) appeared to be more droughttolerant than maize: leaf diffusive conductance was better maintained and less reduction in dry matter occurred. Field-grown plants of different age might however differ markedly from plants grown indoors in pots or containers because of root systems, stomatal behaviour, etc... Our results should therefore not be extrapolated. It can be concluded, however, that the species appears to present some interest and it seems worthwhile to continue the investigations with interspecific crosses and field trials.

\section{REFERENCES}

Algans J. L., Desvignes P., 1984. Action d'un déficit thermique et d'un déficit hydrique simultanés sur le rendement du maïs et ses composantes, 477-482. In Gallais A. : "Physiologic du mais ". Communication au Colloque Physiologie du maïs. Royan 15-17 mars 1983. I.N.R.A., Paris

Beadle C. L., Stevenson K. R., Neumann H. H., Thurtell G. W., King K. M., 1973. Diflusive resistance, transpiration and photosynthesis in single leaves of corn and sorghum in relation to leaf water potential. Can. J. Plant Sci., 53, 537-544.

Crosbie T. M., Pearce R. B., Mock J. J., 1981. Recurrent phenotypic selection for high and low photosynthesis in two maize populations. Crop Sci., 21, 736-740

Farquhar G. D., Sharkey T. D., 1982. Stomatal conductance and photosynthesis. Annu. Rev. Plant Physiol., 33, 317-345.

Galinat W. C., 1980 : Diploperennis, a premaize teosinte of value in corn breeding. Maize Genet. Coop. Newsl., 54, 120.

Gay J. P., 1984. Fabuleux maïs, histoire et avenir d'une plante. Ed. "Association générale des producteurs de maïs». France. 295 p.

Golberg A. D., Ledent J. F., Lannoye R., 1986. Fluorescence induction and water stress in maize and Zea diploperennis. Arch. int. Physiol. Biochim., 94, pp. 48-00.

Hanson I. E., Mahlakshmi V., Alagarswamy G., Bidinger F. R., 1983. An association between flowering and reduced stomatal sensitivity to water stress in pearl millet (Pennisetum americanum (L.) Leeke). Aim. Bot. . 52, 641-648.

Iltis H. H., Doebley J. F., Guzman M. R., Pazy B., 1979. Zea diploperennis (Gramineae) : a new teosinte from Mexico. Science, 203, 186-188
Kemp D. R., Blacklow W. M., 1984. Estimates of leaf photosynthesis with gas flow and times of feeding and sampling when measured by ${ }^{14} \mathrm{CO}_{2}$ in small unventilated cuvettes. Photosynthetica, 18, 344-349.

Krieg D. R., Hutmacher R. B., 1986. Photosynthetic rate control in sorghum (Sorghum bicolor) : stomatal and nonstomatal factors. Crop Sci., 26, 112-117.

Morizet J., Pollacsek M., Togola D., 1984. Tolérance à la sécheresse de 4 variétés de maïs. Essai de mise en évidence des mécanismes impliqués, 493-501. In Gallais A. : "Physiologie du maïs ». Communication au Colloque Physiologie du maïs. Royan 15-17 mars 1983. I.N.R.A., Paris.

McPherson H. G., Boyer J. S., 1977. Regulation of grain yield by photosynthesis in maize subjected to a water deficiency. Agron. J., 69, 714-718

Morot-Gaudry J. F., Farineau J., Rocher J. P., Jolivet E., 1981. Modifications dans les premières étapes de l'assimilation photosynthćtique du carbone chez le maïs sous l'effet du génotype. Agronomie, 1, 739-744.

Renard C., Ndayishimie V., 1982. Etude des relations hydriques chez Coffea arabica L.: comparaison de la presse à membrane et de la chambre a pression pour la mesure du potentiel hydrique foliaire $(\psi)$. Café Cucao Thé, XXVI, 27-30.

Shimshi D., 1969. A rapid field method for mcasuring photosynthesis with labelled carbon dioxide. J. Exp. Bot., 20, 381-401.

Van Dijck E., Ledent J. F., 1984. Comparison of photosynthetic rates measured with IRGA and a rapid ${ }^{14} \mathrm{CO}_{2}$ pulse method. Arch. int. Physiol. Biochim., 92 (5), PF 32.

Vieira da Silva J., 1976. Water ultrastructure and enzymatic activity, 207-224. In Lange O. L., Kappen L. Schulze E. D. : Ecological studies analysis and synthesis. Vol. 19: Water and Plant Life. SpringerVerlag, Berlin, Heidelberg. 